\title{
La gammaglobulina previno la transmisión sexual de hepatitis C
}

Sexual transmission of the hepatitis $C$ virus and efficacy of prophylaxis with intramuscular inmmune serum globulin. Piazza M, Saglioca L,Tosone G. Archives of Internal Medicine. 1997,157:1537-1544.

\section{Objetivo}

Estimar el riesgo de transmisión sexual de la hepatitis C (HCV) y determinar el valor de la profilaxis de la administración periódica de gammaglobulina intramuscular.

\section{Diseño}

Ensayo clínico simple ciego, randomizado controlado.

\section{Lugar}

Universidad de Nápoles y Catanzaro, sur de Italia.

\section{Pacientes}

Participaron 899 parejas heterosexuales de pacientes HCV (+), que tuvieran niveles normales de transaminasas y serolgía HCV (-).

\section{Intervención}

Las parejas sexuales de los pacientes $\mathrm{HCV}(+)$ fueron asignadas a recibir $4 \mathrm{ml}$. IM de inmunoglobulina sérica polivalente al $16 \%$ cada 2 meses ( preparada de donantes a los que no se les había realizado sero-
Logía para HCV, $n=450$ o placebo, $n=449$. Se realizaron controles cada 4 meses para detectar infección por HCV(seroconversión).

\section{Medición de resultados principales}

Detección de anticuerpos ( $\mathrm{HCV}+$ ) por ELISA y confirmado por PCR en las parejas sexuales previamente negativas.

\section{Resultados Principales}

El 98\% de las parejas sexuales (884) completaron el estudio, de las cuales 7 se infectaron con HCV: 6 en el grupo placebo (incidencia: 12 por mil personas-año, IC95 \% 3-22; RR respecto al grupo inmunoglobulina 10.7 [1.2-93.8]) y 1 en el grupo inmunoglobulina sérica (incidencia 1,98 por mil personas-año, IC 95\% 0-5,8). El riesgo de infección fue significativamente más alto para las parejas en el grupo placebo (aproximadamente el $1 \%$ por año $p=0.03$ ).

\section{Conclusiones}

La hepatitis C puede ser transmitida sexualmente. La inmunoglobulina polivalente utilizada redujo significativamente el riesgo de contagio. El tratamiento fue seguro y bien tolerado.

\section{COMENTARIO}

Diferentes estudios epidemiológicos coinciden en la posibilidad de transmisión sexual de hepatitis $C$, pero el contacto heterosexual no representa más del 6 a $8 \%$ entre los factores de riesgo identificados de contagio (1).

Esta vía de transmisión parece ser ineficiente si lo comparamos a otras enfermedades de transmisión sexual como la hepatitis B. Lo más característico de esta enfermedad es que el modo de transmisión no es identificable en el 30 a $50 \%$ de los casos.

Lo recomendado hasta el presente es:

1. Informar al paciente $\mathrm{HCV}(+)$ que existe una pequeña pero real posibilidad de transmisión sexual delvirus, especialmente en personas inmunocomprometidas.

2. A pesar de una cuestionable detección de marcadores HCV en la saliva, no hay evidencia convincente que la enfermedad pueda ser transmitida por besos.

3. Una relación sexual monogámica de larga data probablemente no necesite mas precaución que la abstención cuando algún sangrado este presente (menstruación, hematuria) o ante la presencia de ulceraciones genitales.

4. Una conducta sexual promiscua requiere prácticas de sexo seguro incluyendo el uso de profiláctico.

5. Lo más difícil es aconsejar a una pareja que iniciará una relación sexual con la idea de establecer una relación monogámica a largo plazo. Se aconseja exponer la situación claramente "y que la pareja decida cuando el riesgo percibido por ellos es suficiente para utilizar en forma rutinaria el profiláctico" (1).

Estudios realizados en 1977, antes de la posibilidad de detección del HCV ya hablaban de la reducción del riesgo de desarrollar la enfermedad clínica y hepatitis crónica con el uso de inmunoglobulina sérica en la hepatitis post-transfusional (2) y en 1990 el autor de este mismo trabajo sugi- rió que la inmunoglobulina puede ser efectiva como profilaxis de la transmisión sexual del HCV (3).

Durante una infección por HCV pueden detectarse diferentes anticuerpos anti-HCV, pero en general se afirma que estos anticuerpos no confieren inmunidad ni contribuyen al "clearance" del virus (4), por lo que el uso de inmunoglobulina ha sido cuestionado.

Sin embargo, estudios experimentales en chimpances han demostrado que anticuerpos homólogos contra las glicoproteínas de la cápside viral (gPE1 y gPE2) los protegen de la infección.

En el presente trabajo los autores han utilizado inmunoglobulina preparada a partir de donantes a los que no se les realizó screening para HVC, esto significa que no se desechó la sangre de los donantes HVC (+). Para demostrar la presencia de anticuerpos contra las glicoproteinas de la cápside se utilizó el test de ELISA y su poder de neutralización con un test cuantitativo de reciente aplicación (5).

La transmisión ocurrió en parejas sexuales de pacientes con enfermedad hepática activa (incluyendo cirrosis), de mayor edad (explicable por mayores niveles de viremia) y de mayor tiempo de relación sexual.

La inmunoglobulina brindó protección estadisticamente significativa contra la transmisión sexual del HCV.

Este estudio fue interrumpido en marzo de 1993 cuando en Italia por ley se obligó a realizar "screening " de HCV a donantes.

Como actualmente la inmunoglobulina se prepara de donantes HCV (-), no contiene anticuerpos neutralizantes y no es efectiva como profilaxis.

Los autores sugieren la preparación de inmunoglobulina hiperinmune específica anti-HCV a partir de donantes (+), la que podría ser utilizada en profilaxis de transmisión sexual, vertical, pacientes en hemodiálisis, contactos de grupos de riesgo y para prevenir reinfección en receptores de transplante. Imagino que este avance será de mayor impacto global para esta enfermedad que el tratamiento con interferón de la hepatitis crónica activa.

\section{Dr. Juan Andrés Torres.}

Servicio de Clínica Médica. Hospital Italiano de Buenos Aires.

\section{Referencias}

1. Spousal transmissión of the HCV? Seef L, Alter H. Ann Intern Med. 1994, 120: 807-809.

2. A randomized, double-blind, controlled trial of the efficacy of inmune serum globulin for the prevention of post-transfusion hepatitis. Seef L, Zimmerman H. Gastroenterology. 1977, 72: 111-121.

3. Periodic gammaglobulin to prevent hepatitis C in at risk sexual partners. Piazza M. Lancet. 1990, 336: 828-824.

4. HCV in multiple episodes of acute hepatitis in polytransfused thalassaemic children. Lai M. Lancet. 1994, 343: 388-390.

5. A quantitative test to estimate neutralizing antibodies to the HCV. Rosa D. Proc Natl Acad Sci USA. 1996, 93: 1759-1763. 